\title{
REVIEW
}

\section{Rewriting the World Colonialism Made}

\author{
Alexandria Smith \\ University of Virginia, US \\ ans141@womenstudies.rutgers.edu
}

Review of Dionne Brand, An Autobiography of the Autobiography of Reading. CLC Kreisel Lecture Series, University of Alberta Press, 2020. 52 pages.

Keywords: Dionne Brand; autobiography; memoir; queer Caribbean memoir; literary history

Dionne Brand's essay An Autobiography of the Autobiography of Reading, published in 2020 as part of the Canadian Literature Centre Kreisel Lecture Series, develops autobiography beyond the terms of literary genre, instead deploying it as a tool for theorizing relationships between history, subjectivity, and narrative in a context of imperialism.

Totaling under fifty full pages of text, An Autobiography is brief but powerful. The first of the essay's five sections opens with an autobiographical anecdote, a reflection on a photograph taken early in Brand's childhood which was intended to be sent to Brand's mother and aunt, living and working as nurses in England. At the close of this section readers are offered a meditation on how the indefinite and definite articles of the essay's title gesture towards two primary areas of concern in the text. "An autobiography gestures to the world of a reading self. It signals the complicated ways of reading and interpretation that are necessary under conditions of coloniality" (Brand 8, emphasis in original). On the other hand, "the Autobiography identifies the subject who is supposed to be made, through colonial pedagogies in the forms of textsfiction, non-fiction, poetry, photographs, and governmental and bureaucratic structures" (ibid, emphasis in original). Brand's essay articulates colonial worldmaking, the production of colonial ways of being and knowing within human subjects, as consonant with the production of colonial literary and institutional texts. In describing the photograph, Brand is attentive to the ways the photographer, Brand's mother and aunt abroad, and she and her siblings are conscripted into the logics of imperial relations between center and periphery. The camera and the photograph serve as tools for disciplining imperial-qua-photographic subjects and yet "the photo cannot hold the girls in" (Brand 6). ${ }^{1}$ The remainder of the essay explores various textual hailings, through photographs and through literature.

We might understand the making and unmaking of its readers which Brand proposes that literature undertakes, which encompasses both the use of narrative to communicate beliefs and values and to interrupt the ability to see oneself, as a form of disidentification. Disidentification, most notably elaborated by José Esteban Muñoz, is a strategy of recognizing aspects of alignment with dominant cultures and simultaneously being in excess of those dominant cultures. The genres of memoir and autobiography are rich sites for understanding the kinds of disidentification which shape queer and Caribbean subjects' relationships to dominant culture. Memoir can seduce with its suggestions of transparency, that we may be able to know the author more fully through reading a faithful and coherent narrative of their life. In her work on blogging as a self-representative technology employed by queer Jamaican authors in the mid-2000's, Kelly Baker Josephs argues that the technology and format of blogging allow these authors to evade the transparency sought through faithful and transparent narratives, and instead to tell stories about their lives through "gaps, paradoxes, and silences" (Baker Josephs, no page number). An Autobiography impedes the reader's quest for what Baker Josephs calls, citing Lisa Lowe, "the fluid story of a unitary [author]" (ibid). Instead,

\footnotetext{
${ }^{1}$ For more on photography, colonialism, and Black subjects, see Tina Campt's Image Matters: Archive, Photography, and the African Diaspora in Europe, Duke University Press, 2012.
} 
Brand has given us a literary memoir which troubles the lines between literary history and personal history, creating a multi-textured discussion of queer ways of reading without satisfying the expected portrayals of queerness-as-sexual difference. In this way, An Autobiography participates in the broader tradition of the use of autobiography to situate oneself in history, as well as the growing queer Caribbean autobiographical tradition of narrating through 'gaps, paradoxes, and silences' inherent to refusing transparency.

Throughout An Autobiography Brand examines the roles colonial texts and their authors-including William Thackeray and Charlotte Brontë-play in creating the worlds which imperialism desires. For instance, Brand reads C.L.R. James' grappling with Thackeray's portrayal of "the British reticence, the British self-discipline, the stiff lips, upper and lower," as well as James' analysis of cricket's impact on social life in the West Indies, as confrontations with British colonial worldmaking. She then discusses her own readings of Thackeray as a series of disidentifications, remarking on Vanity Fair's construction of Black femininity as a stereotypical foil to white femininity and the narrative pursuit of empathy for $18^{\text {th }}$ century white settler colonists in what is now the United States in The History of Henry Esmond, Esq.

Significantly, Brand's analyses of these texts are explicitly framed through her acts of reading and rereading them. She writes, referring to her encounter with The History, "I cannot do what the reader is hailed to do, which is to juxtapose the refinement, good taste, beauty, and rectitude of ... England, against the dreadful siege and terror of the Indians. The reader occupying the autobiography of reading" (Brand 22). Through close attention to the narrative structure and emotional register of the language of this novel, Brand identifies The History of Henry Esmond, Esq. as both addressing itself to and laboring to construct an ideal reader who is, by necessity, a subject for whom white settler colonial conquest is an unqualified moral good. Brand's autobiography is thus found in her use of the first-person as well as her description of the disidentification of reading as a colonized and racialized subject. Brand thus builds on Muñoz's intervention through naming a queer subject's-her own-relationship to dominant culture as well as by illustrating a queer subject's queer relationship to dominant culture. She is a consumer of colonial literature, yet never its ideal reader. This relationship illustrates how queerness and Blackness share marginality within colonial worldmaking.

An Autobiography emphasizes the production of narrative, specifically counternarrative, as a means of negotiating one's position within the colonial world. Readers of Brand's other works will recognize the description of her short story "At the Lisbon Plate" as a counternarrative, an intentional revision, of French author Albert Camus' 1942 novella The Stranger. ${ }^{2}$ Brand positions her counternarrative within a genealogy of Jean Rhys' 1962 novel Wide Sargasso Sea, which imagines a life history for Bertha Mason, the sublimated white Creole antagonist of Charlotte Brontë's Jane Eyre (1848). Brand reads Brontë's reliance on "the excesses of the plantation, the violence un-regarded as violence; experienced as power, wealth, and wellbeing," such that slavery and imperialism directly-yet silently-inform the material context of Jane Eyre (Brand 31). While Wide Sargasso Sea draws the colonial subtext to the level of the surface by enfleshing the life of Bertha Mason/Antoinette Cosway, "a reader like me," Brand writes, notices Rhys' failure to meaningfully address the violent absenting of Blackness from Jane Eyre's world, thus producing another moment of disidentification (Brand 35). Wide Sargasso Sea therefore participates in the literary colonial worldmaking which, in Brand's terms, renders Black people into black figures. ${ }^{3}$

As counternarratives still involve responding to a dominant narrative which remains at the center, $A n$ Autobiography of the Autobiography of Reading also offers examples of Black texts which refuse conscription into colonial worldmaking. Wilson Harris' Palace of the Peacock and Gwendolyn Brooks' Maud Martha invite the reader "to construct the narrative's coherence without requiring the presumption of an abject location" (Brand 43). These texts do not only counter the presumptions of coloniality, they refuse entirely to engage them. Narrative structure is used to construct the world as a product of colonial ways of being, and it is also used to construct the spaces of freedom which reflect the interiority of Black life.

The essay's conclusion returns to read the site of the photograph taken of Brand and her sisters and cousins in childhood. The photograph is a document shaped in the context of colonial and imperial domination, and yet in the image of her young self, unsettled in the frame, Brand sees "resistance ... to the autobiography of the composed subject" (Brand 50). An Autobiography of the Autobiography of Reading commits itself to revealing the ways that people use narrative to construct themselves and others. Brand's analysis of

\footnotetext{
${ }^{2}$ In the text, Brand translates the French title L'Étranger as The Outsider.

3 Brand 35. This argument resonates with Toni Morrison's argument that United States literature has relied on an absented presence of Blackness to construct U.S. whiteness. See Toni Morrison. Playing in the Dark: Whiteness and the Literary Imagination. Vintage Books, 1992
} 
literature from the perspective of a text's audience draws attention to the ways particular readers' responses illustrate the authors' investment in particular forms of power. The essay therefore highlights the phenomenon of encountering a narrative, not simply its creation. The effect of this development throughout the essay is that Brand illustrates individual life histories and narratives as inextricable from the broader historical and cultural processes they are situated within. This insight permeates Brand's extensive body of writing, making An Autobiography the latest in a long line of textual encounters with the world-making work of reading and writing.

\section{Competing Interests}

The author has no competing interests to declare.

\section{References}

Baker Josephs, Kelly. "Me, Myself, and Unno: Writing the Queer Caribbean Self into Digital Community." archipelagoes 5 (December 2020). http://archipelagosjournal.org/issue05/josephs-blogging.html.

Brand, Dionne. An Autobiography of the Autobiography of Reading. U of Alberta P, 2020.

-_-. "At the Lisbon Plate" in Sans Souci, and Other Stories. Williams-Wallace, 1988.

Brontë, Charlotte. Jane Eyre. Service and Patton, 1897, First published 1847.

Brooks, Gwendolyn. Maud Martha. Third World Press, 1991.

Campt, Tina. Image Matters: Archive, Photography, and the African Diaspora in Europe. Duke UP, 2012. DOI: https://doi.org/10.2307/j.ctv125jqhg

James, C.L.R. Beyond a Boundary. Pantheon, 1963.

Harris, Wilson. Palace of the Peacock. Faber and Faber, 2013, First published 1966.

Muñoz, José Esteban. Disidentifications: Queers of Color and the Performance of Politics. U of Minnesota P, 1999.

Rhys, Jean. Wide Sargasso Sea. W.W. Norton \& Company, 2016, First published 1966.

Thackeray, William Makepeace. Vanity Fair. Dover Thrift Editions, 2016, First published 1848.

--.. The History of Henry Esmond, Esq. Penguin, 1970, First published 1852.

How to cite this article: Smith, A 2021 Rewriting the World Colonialism Made. Anthurium, 17(1): 6, 1-3. DOI: https://doi.org/10.33596/anth.450

Published: 01 September 2021

Copyright: $\odot 2021$ The Author(s). This is an open-access article distributed under the terms of the Creative Commons Attribution 4.0 International License (CC-BY 4.0), which permits unrestricted use, distribution, and reproduction in any medium, provided the original author and source are credited. See http://creativecommons.org/licenses/by/4.0/. 